\title{
Deformational behaviour of fly-ash based geopolymer concrete at temperatures of up to $150^{\circ} \mathrm{C}$
}

\author{
M Talha Junaid ${ }^{1}$ \\ ${ }^{1}$ Assistant Professor, University of Sharjah, Sharjah, UAE
}

\begin{abstract}
The use of Geopolymer Concrete $\left(\mathrm{GP}^{*} \mathrm{C}\right)$ has been on the rise over the last few decades owing to its lower carbon emissions as compared to Ordinary Portland Cement Concrete (OPC). Recent research has also established the superior thermal properties of GPC and makes it an ideal construction material for specialized application. However, the deformational behaviour of GPC at elevated temperatures has not fully understood. If GPC is to be used as a main stream construction material for specialized applications, the exact deformational behaviour of the material under thermal loading needs to be investigated. This paper looks into the deformational characteristics of GPC (with natural crushed siliceous aggregates) when dry heated up to $150^{\circ} \mathrm{C}$ at near zero loading. The deformations recorded using a clip-on extensometer are used to determine the strains developed in the GPC samples due to thermal loads. Coefficient of thermal expansion (CTE) for the tested GPC samples was found and was comparable to OPC concrete at the tested temperatures. Between ambient $\left(20^{\circ} \mathrm{C}\right)$ and $80^{\circ} \mathrm{C}$ the CTE for GPC was determined to be between $10.3-10.9 \times 10^{-6} \mathrm{~mm} / \mathrm{mm} /{ }^{\circ} \mathrm{C}$ which is similar to OPC concretes. CTE for temperatures between $80^{\circ} \mathrm{C}$ and $150^{\circ} \mathrm{C}$ was determined to be $9.3-10.0 \times 10^{-6}$ $\mathrm{mm} / \mathrm{mm} /{ }^{\circ} \mathrm{C}$. First heating cycles resulted in much lower CTE which may be due to the presence of evaporable water in the samples. Like OPC, GPC is a non-homogeneous material and the variation in the materials between samples account for the slight variation in the CTE values determined.
\end{abstract}

\section{Introduction}

Alkali liquids (usually a soluble metal hydro-oxide and/or alkali silicate) can be used to react with silica $\left(\mathrm{SiO}_{2}\right)$ and alumina $\left(\mathrm{Al}_{2} \mathrm{O}_{3}\right)$ rich natural materials, like metakaolin or with industrial by-products, like Fly Ash (FA), Silica Fume (SF), Rice Husk Ash (RHA) or Slag to produce binders [1-3]. Such binders mixed with typical coarse and fine aggregates can form concrete, usually known as Geopolymer Concrete, with mechanical and thermal properties comparable or even superior to ordinary concrete. The term "Geopolymers" was coined as the chemical reaction between the aluminosilicates and the alkaline liquid was a polymerization resulting from a source material of natural or geological origin. Although

\footnotetext{
${ }^{*}$ Corresponding author: mjunaid@sharjah.ac.ae
} 
other researchers prefer using the term alkali activated FA (AAFA) when FA is used as a source of aluminosilicates, alkali activated Slag when Slag is the source of aluminusilicates, and so on [4].

\subsection{Nature and characteristics of geopolymer concrete}

Researchers agree that the basic reaction mechanism for formation of geopolymer binders is in three stages namely: dissolution of $\mathrm{Si}$ and $\mathrm{Al}$ from the source material, hydrolysis or gelation, and condensation forming a 3D network of silico-aluminates also termed as the 'geopolymer backbone' [1, 2, 4-8]. Davidovits describes geopolymerization as an exothermic reaction and has schematised it using the two stage equation (1) given below [2].

$\mathrm{Si}-\mathrm{Al}$ source + Silicates + Water + Alkaline Liquid $\rightarrow \quad$ Geopolymer Precursor

$$
\left(\mathrm{Si}_{2} \mathrm{O}_{5}, \mathrm{Al}_{2} \mathrm{O}_{2}\right) \mathrm{n}+\mathrm{nSiO}_{2}+\mathrm{nH}_{2} \mathrm{O} \stackrel{\mathrm{NaOH}, \mathrm{KOH}}{\longrightarrow} \mathrm{n}(\mathrm{OH})_{3}-\mathrm{Si}-\mathrm{O}-\stackrel{(-)}{\mathrm{Al}}-\mathrm{O}-\mathrm{Si}-(\mathrm{OH})_{2}
$$

Geopolymer Precursor + Alkaline Ions $\rightarrow \quad$ Geopolymer Backbone

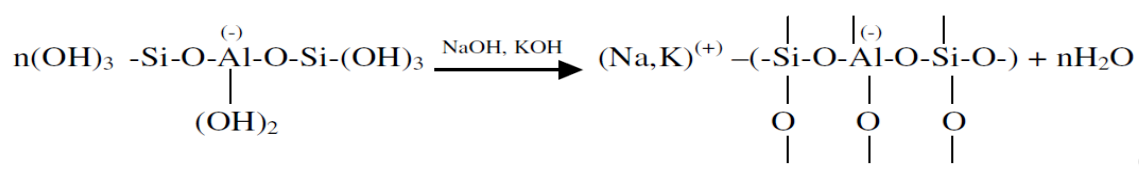

GPC does not require any Portland cement as a binder. The role of FA in GPC is entirely different from that when it is used as a cement replacement material in OPC concrete to enhance certain properties such as workability or to reduce the heat of hydration. In such cases FA has no pronounced effect on the strength of concrete [9] especially early strength, however, in fly ash based GPC the fly ash is the sole source of aluminosilicates for reaction with the alkaline solution to form the binder and is thus a critical factor in strength development. Coarse and fine aggregates make up 75 to $80 \%$ of the mass of GPC, as is the case with OPC concrete. Though extensive research is being conducted to determine and understand the chemical composition of GPC and the factors affecting it, the focus is now shifting to probable applications to civil and infrastructural engineering.

Currently there is sufficient evidence to suggest that geopolymer concrete has a better resistance to fire than OPC concrete [10-13]. However, most of the existing data deal with the strength or spalling of small laboratory samples [14-17]. Except for the work of Rickard et al. [12], Provis et al [18], Junaid et al. [19-22] and Pan et al. [23] on the thermal dilatation of geopolymer pastes, mortars and concrete synthesised from fly ashes of variable composition, very little is known about its deformational behaviour, creep and thermal properties of GPC. If GPC is to be used as an alternate to OPC the thermal properties of GPC need to be investigated.

The major difference between geopolymer concrete and OPC concrete is in the intrinsic chemistry of the binders. OPC attributes its strength to the hydration of cement which results in the formation of, among other compounds, C-S-H and $\mathrm{Ca}(\mathrm{OH})_{2}$. The strength of the binder largely depends on these two compounds. Moreover, the presence of moisture 
and, in particular, its movements affects the thermal properties. GPC on the other hand develops its strength from the reaction of $\mathrm{Al}$ and $\mathrm{Si}$ with alkaline solutions as described above in equation (1) [24, 25]. It is therefore hypothesised that the movement of water within the geopolymer matrix will have a less significant effect on the thermal properties of GPC. This paper looks at the deformational behaviour of GPC when dry heated up to $150^{\circ} \mathrm{C}$ at near zero loading.

\section{Experimental work}

\subsection{Materials}

Low calcium Class F fly ash with composition as found using X-Ray Fluorescence (XRF) is tabulated in Table 1 was used in this study. Sodium silicate and sodium hydroxide were used as alkaline activators in this study. Laboratory grade D sodium silicate solution (Na2SiO3) with $\mathrm{SiO} 2 / \mathrm{Na} 2 \mathrm{O}$ between 1.95 and 2.05 was procured from IMCD Australia Limited. Sodium Hydroxide solutions (12M) were made from $98 \%$ purity flakes supplied by Redox Pyt Ltd., Australia. The silicate to hydroxide ratio was kept constant at 2.5 by weight of solutions. Locally sourced, natural crushed aggregates (nominal sizes 14, 10 and $7 \mathrm{~mm}$ ) along with river sand as fine aggregates were used in the mix.

Table 1. X-Ray Fluorescence (XRF) of Fly Ash Used.

\begin{tabular}{|l|c|}
\hline Compound & \% Composition by Weight \\
\hline $\mathrm{SiO}_{2}$ & 62.19 \\
\hline $\mathrm{Al}_{2} \mathrm{O}_{3}$ & 27.15 \\
\hline $\mathrm{Fe}_{2} \mathrm{O}_{3}$ & 3.23 \\
\hline $\mathrm{CaO}$ & 1.97 \\
\hline $\mathrm{K}_{2} \mathrm{O}$ & 0.89 \\
\hline $\mathrm{TiO}_{2}$ & 1.06 \\
\hline $\mathrm{MgO}$ & 0.4 \\
\hline $\mathrm{Na}_{2} \mathrm{O}$ & 0.3 \\
\hline $\mathrm{SO}_{3}$ & 0.07 \\
\hline $\mathrm{L} . O . I^{\mathrm{O}}$ & 1.75 \\
\hline $\begin{array}{l}\mathrm{Sum} \text { of } \\
\mathrm{Alumino} \text {-silicates }\end{array}$ & 89.34 \\
\hline $\mathrm{SiO}_{2} / \mathrm{Al}_{2} \mathrm{O}_{3}$ & 2.29 \\
\hline
\end{tabular}

\subsection{Specimen preparation}

Aggregates were dry mixed with fly ash for 2 minutes. The silicates solution was then added to the dry mix and mixed for 3 minutes. Hydroxide was then added and mixed for 2 more minutes. Additional water along with any plasticizer was then added and mixed for additional 2 minutes. The mix design used in this study is summarized in Table 2. Cylinders with nominal measurements of $75 \mathrm{~mm}$ dia and $150 \mathrm{~mm}$ height were mixed and casted using the procedure described elsewhere [26]. The samples, after an initial rest 
period, were cured for 48 hours at $80^{\circ} \mathrm{C}$. The samples were then placed in an environmental room with $\mathrm{RH}$ of $50 \%$ and temperature of $23^{\circ} \mathrm{C}$ till the time of testing.

Table 2. Composition and Mean Compressive Strength of GPC samples.

\begin{tabular}{|c|c|c|c|c|c|c|c|}
\hline $\begin{array}{c}\mathrm{FA} \\
\left(\mathrm{kg} / \mathrm{m}^{3}\right)\end{array}$ & $\begin{array}{c}\mathrm{NaOH} \\
\left(\mathrm{kg} / \mathrm{m}^{3}\right)\end{array}$ & $\begin{array}{c}\mathrm{Na}_{2} \mathrm{SiO}_{3} \\
\left(\mathrm{~kg} / \mathrm{m}^{3}\right)\end{array}$ & $\begin{array}{c}\text { Coarse } \\
\left(\mathrm{kg} / \mathrm{m}^{3}\right)\end{array}$ & $\begin{array}{c}\text { Fine } \\
\left(\mathrm{kg} / \mathrm{m}^{3}\right)\end{array}$ & $\begin{array}{c}\text { Water } \\
\left(\mathrm{kg} / \mathrm{m}^{3}\right)\end{array}$ & $\begin{array}{c}\mathrm{VM}^{\wedge}+\mathrm{SP}^{\wedge} \\
\left(\mathrm{kg} / \mathrm{m}^{3}\right)\end{array}$ & $\begin{array}{c}f_{c}{ }^{\prime} \\
(\mathrm{MPa})\end{array}$ \\
\hline 420 & 60 & 150 & 1190 & 574 & 32.3 & 8 & 41 \\
\hline
\end{tabular}

$\wedge^{\wedge}$ iscosity Modifier and Superplasticizer

\subsection{Test procedure}

The GPC cylindrical samples were fitted with steel rings made from 316 grade steel with knife edges machined on them. A high temperature clip on extensometer was clamped on the knife edge (Figure 1a) and connected to a data acquisition software which was programmed to collect data at $10 \mathrm{~Hz}$.

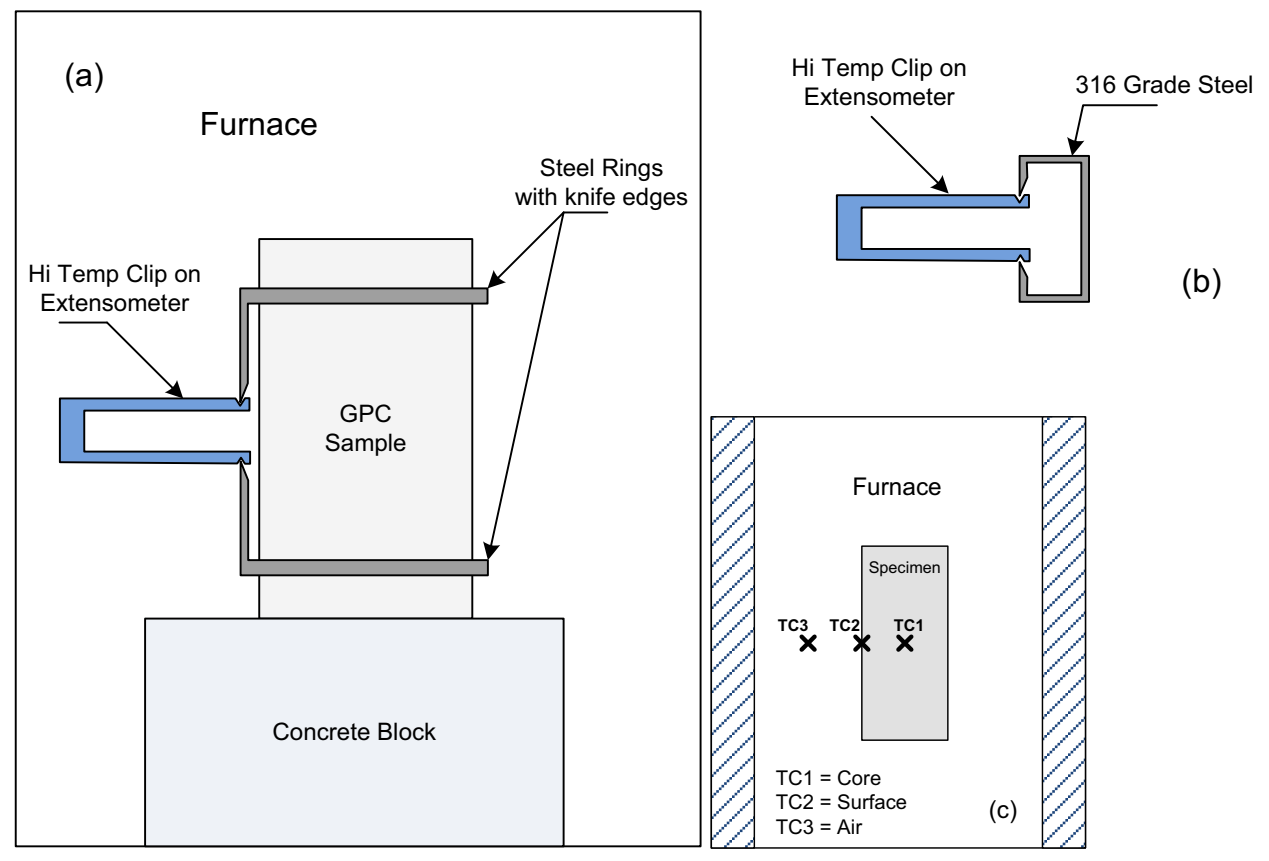

Fig. 1. Schematic representation of (a) test setup (b) strains in steel and (c) thermocouple placement in the furnace.

K-type thermocouples were placed at the core (embedded in the core), at the surface of the sample as well as within the furnace to collect temperature data with time (Figure 1c). To calibrate the clip-on extensometer, it was attached to a titanium silicate sample with a coefficient of thermal expansion (CTE) of $0.008 \times 10^{-6} \mathrm{~mm} / \mathrm{mm} /{ }^{\circ} \mathrm{C}$. The displacement readings obtained were used to calibrate the extensometer at the test temperatures (by subtracting these values from the test results). These values were averaged by repeating the test 5 times for each test temperature. The tests were repeated using a 316 Grade steel Cshape to establish the CTE of the steel used (Figure 1b). During calculation of the final 
concrete strain, the strains due to steel and the deformation caused within the high temperature extensometer were accounted for. This is further discussed in the results section. Use $170 \times 250 \mathrm{~mm}$ paper size (W x H mm) and adjust the margins to those shown in the Table 1.

The samples were heated at $4.5^{\circ} \mathrm{C} / \mathrm{min}$ until it reached the target temperatures. The temperature was then maintained for 2 hours to ensure thermal equilibrium. The furnace was then turned off and the sample allowed to cool within. Strains were measured during the ramp-up, soak, and cool down stages.

\section{Results and discussion}

Figure 2 represents the deformation of the different elements on the test specimen. The 'Total' displacement represents the displacement of the system as a whole including the deformation of the extensometer (Exten) computed earlier for this temperature range, the 'True' deformation which is the difference between 'Total' and 'Exten', and the expansion of the steel knife-edges (Steel). The deformation of the GPC sample (GPC) is computed by subtracting the 'Steel' extension from the 'True' deformation.

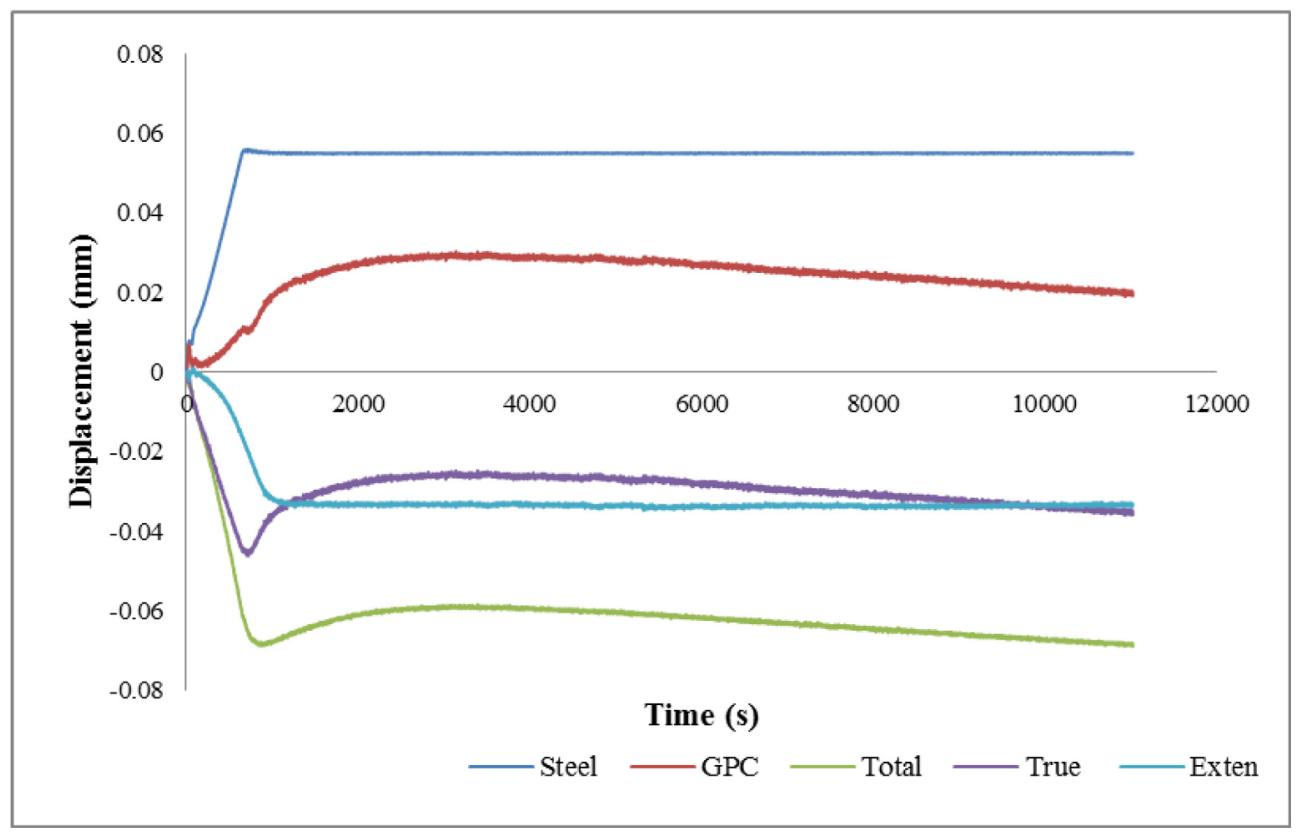

Fig. 2. Displacement readings for the test setup from Ambient to $80^{\circ} \mathrm{C}$.

The displacements represented in Figure 2 were then converted to strains and are shown in Figure 3 and 4 for first, second and third heating cycles of the specimen. It can be noted that the first heating of the specimen undergoes slightly different strains as compared to the subsequent heating cycles, especially during the soak period. After the initial expansion of the GPC specimen, as the temperature is maintained, the sample starts to contract after reaching its peak strain. This can be attributed to the loss of water from the system, resulting in shrinkage. However, subsequent heating cycles reveal that the peak strains reached are slightly higher than those during first heating. This trend was observed in all samples undergoing the heating cycles. Moreover, after the peak strains are reached the strains plateaus for the duration of the heating. 


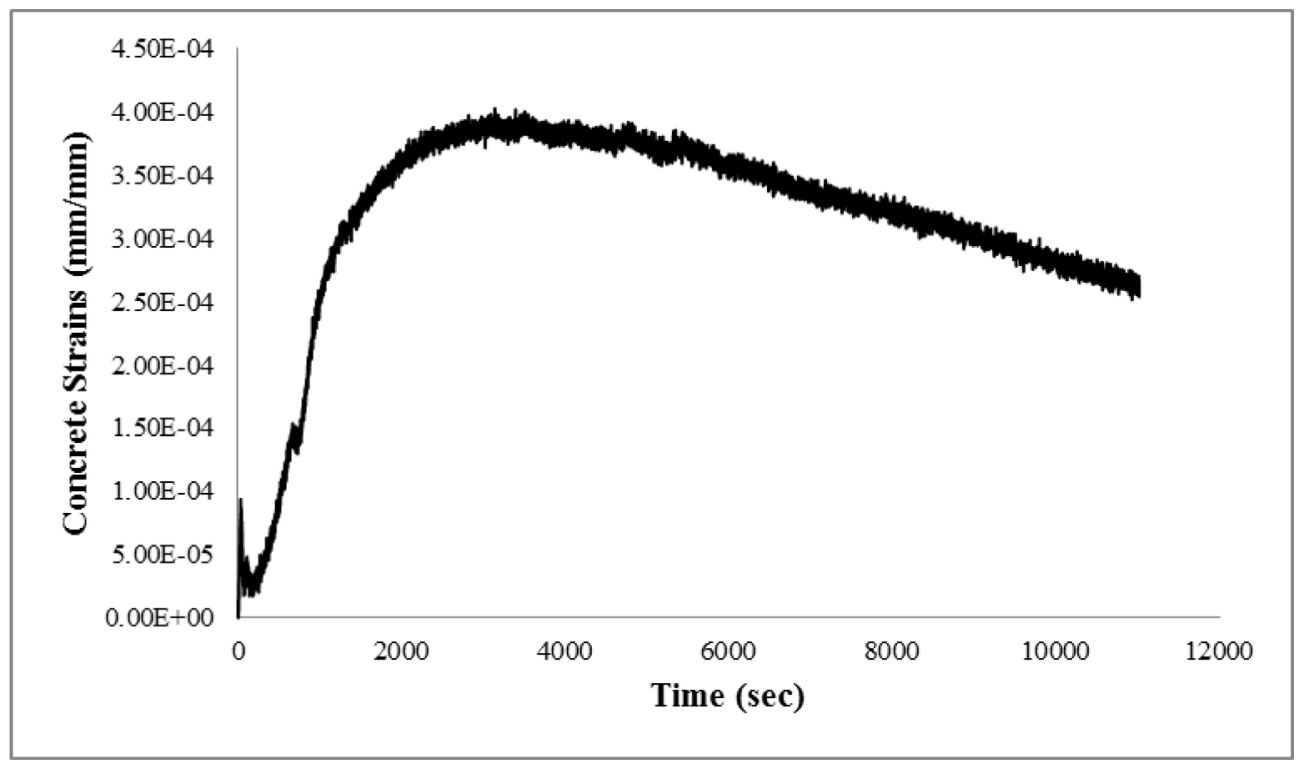

Fig. 3. Concrete Strains between Ambient and $80^{\circ} \mathrm{C}$ (First Heating).

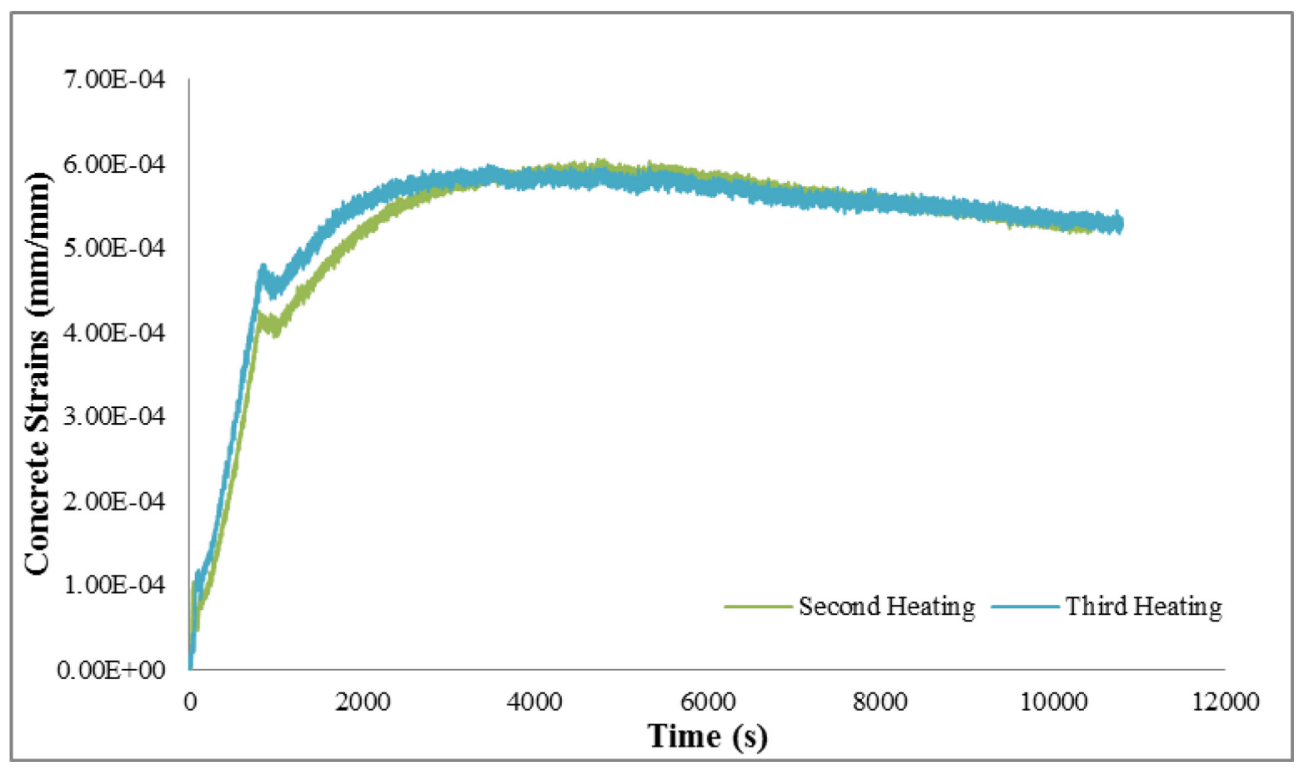

Fig. 4. Concrete Strains between Ambient and $80^{\circ} \mathrm{C}$ (Second and Third Heating).

The Coefficient of Thermal Expansion (CTE) was then calculated using the formula $C T E=\frac{\Delta L}{L} \times \Delta T$ where $\Delta \mathrm{L}$ is the change in length and $\Delta \mathrm{T}$ is the change in temperature over which this change in length was achieved. For the results presented here in Figure 3 and 4 the CTE was computed as $6.9 \times 10^{-6} \mathrm{~mm} / \mathrm{mm} /{ }^{\circ} \mathrm{C}$ for the first heating cycle and $10.27 \times 10^{-6}$ and $10.31 \times 10^{-6} \mathrm{~mm} / \mathrm{mm} /{ }^{\circ} \mathrm{C}$ for the second and third cycles respectively. Three other samples were tested for the same temperature range with the resulting CTE between $10.3-10.9 \times 10^{-6} \mathrm{~mm} / \mathrm{mm} /{ }^{\circ} \mathrm{C}$. The results of the replicate samples are tabulated in Table 3 below. 
Table 3. CTE values based on first, second and third cycle heating from ambient to $80^{\circ} \mathrm{C}$.

\begin{tabular}{|l|c|c|c|}
\hline \multirow{2}{*}{ Sample ID } & \multicolumn{3}{|c|}{ Coefficient of Thermal Expansion } \\
\cline { 2 - 4 } & $\begin{array}{c}\text { First Heating } \\
\left(x 10^{-6} \mathrm{~mm} / \mathrm{mm} /{ }^{\circ} \mathrm{C}\right)\end{array}$ & $\begin{array}{c}\text { Second Heating } \\
\left(x 10^{-6} \mathrm{~mm} / \mathrm{mm} /{ }^{\circ} \mathrm{C}\right)\end{array}$ & $\begin{array}{c}\text { Third Heating } \\
\left(x 10^{-6} \mathrm{~mm} / \mathrm{mm} /{ }^{\circ} \mathrm{C}\right)\end{array}$ \\
\hline Sample 1 & 6.9 & 10.27 & 10.31 \\
\hline Sample 2 & 6.9 & 10.32 & 10.68 \\
\hline Sample 3 & 7.1 & 10.74 & 10.91 \\
\hline Sample 4 & 7.0 & 10.34 & 10.43 \\
\hline
\end{tabular}

Between the temperature range of $80^{\circ} \mathrm{C}$ and $150^{\circ} \mathrm{C}$, the expansion of GPC rose steadily with temperature and became constant after thermal equilibrium was reached (Figure 5 and 6). Unlike between the ambient and $80^{\circ} \mathrm{C}$ temperature range, during this temperature rise there were no dips in the strains after reaching its peak. This behaviour further supports the hypothesis that the decrease in strains during first heating was due to the movement of free water in the GPC system. As the sample has undergone three cycles of heating to $80^{\circ} \mathrm{C}$ earlier most of the free water would have escaped. Any remaining free water would have left the system during the temperature ramp to $150^{\circ} \mathrm{C}$. Therefore, at this temperature range, free water would have had a less pronounced effect on the deformational behaviour.

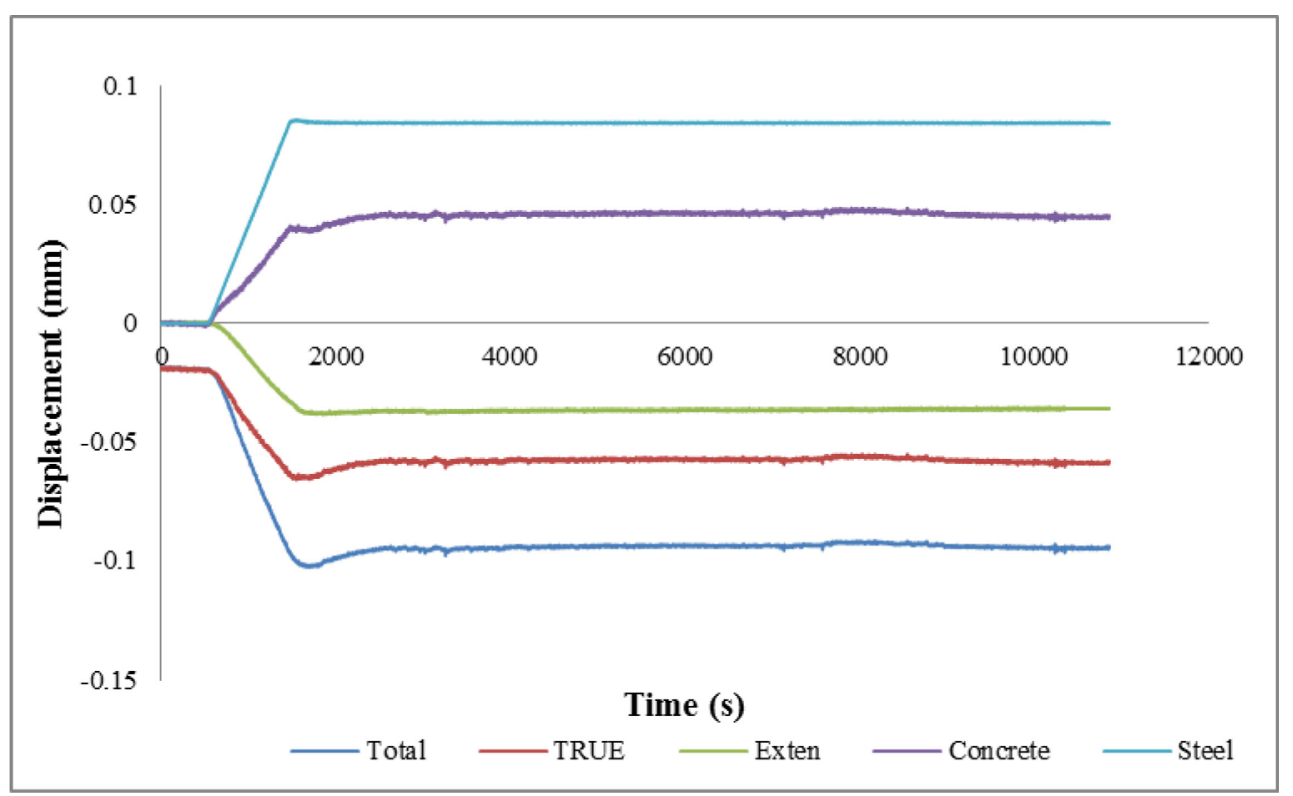

Fig. 5. Displacement readings for the test setup from $80^{\circ} \mathrm{C}$ to $150^{\circ} \mathrm{C}$.

The CTE calculated for this sample using the first and second heating cycle results was 9.15 and $9.31 \times 10^{-6} \mathrm{~mm} / \mathrm{mm} /{ }^{\circ} \mathrm{C}$, respectively. However other samples tested for this temperature ranges resulted in CTE range of 9.3 and $10.0 \times 10^{-6} \mathrm{~mm} / \mathrm{mm} /{ }^{\circ} \mathrm{C}$. 


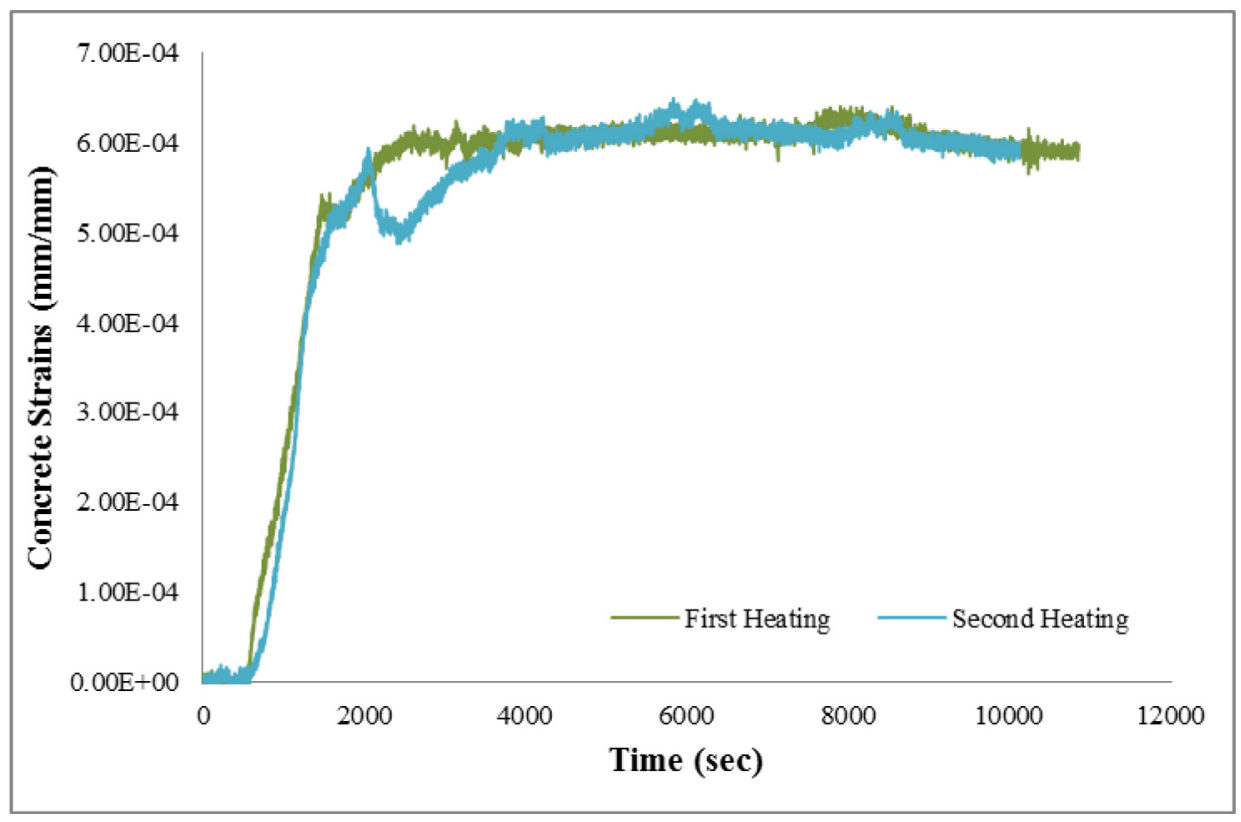

Fig. 6. Concrete Strains between $80^{\circ} \mathrm{C}$ and $150^{\circ} \mathrm{C}$ (first and second heating)

\section{Conclusions}

This paper presents the experimental program to determine the deformational behaviour of low calcium heat cured geopolymer concrete. The deformation of GPC is reported for first and subsequent heating cycles. The GPC samples were heated up to $80^{\circ} \mathrm{C}$ and then subsequently to $150^{\circ} \mathrm{C}$ under near zero loads. The evolution of strains and coefficient of thermal expansion are reported for the tested sample. Based on the results of tests the following conclusions can be drawn:

1. The strain development within GPC samples at near zero loads, depends on the heating cycle of the samples. During first heating the samples to $80^{\circ} \mathrm{C}$, the samples developed slightly lesser peak strains than during subsequent heating cycles. During first heating to $80^{\circ} \mathrm{C}$ and after reaching peak strains the samples contract as the temperature is maintained. This behaviour may be attributed to the movement of free water within the GPC system resulting in shrinkage of the samples.

2. The strains developed during the subsequent heating of the GPC samples to up to $80^{\circ} \mathrm{C}$ results in slightly higher peak strains. During soak periods, the sample strains plateaued in contracts to the first heating cycle where they underwent contraction. This reinforces the hypothesis that the deformational behaviour of GPC under heat loading is dependent on its moisture content and the movement of moisture has a significant impact on its response.

3. The coefficient of thermal expansion of GPC samples is very similar to that of OPC. Between ambient and $80^{\circ} \mathrm{C}$ was determined to be between 10.3 $10.9 \times 10^{-6} \mathrm{~mm} / \mathrm{mm} /{ }^{\circ} \mathrm{C}$. Between $80^{\circ} \mathrm{C}$ and $150^{\circ} \mathrm{C}$ the coefficient of thermal expansion of GPC samples was determined to be $9.3-10.0 \times 10^{-6} \mathrm{~mm} / \mathrm{mm} /{ }^{\circ} \mathrm{C}$, while the $\mathrm{CTE}$ between ambient and $100^{\circ} \mathrm{C}$ was determined to be $11.0 \times 10^{-6}$ $\mathrm{mm} / \mathrm{mm} /{ }^{\circ} \mathrm{C}$. 
The author would like to thank his colleagues at the School of Engineering and Information Technology, UNSW, Canberra for their support during testing. The support provided by the University of Sharjah is also highly appreciated.

\section{References}

1. Davidovits, J. Soft Mineralogy and Geopolymers. in Proceedings of the Geopoolymer 88 International Conference. France.(1988)

2. Davidovits, J., Geopolymers Inorganic polymerie new materials. Journal of Thermal Analysis. 37: p. 1633-1656.(1991)

3. Lloyd, N. and B. Rangan, Geopolymer Concrete with Fly Ash, in Second International Conference on Sustainable Construction Materials and Technologies: Italy.(2010)

4. Fernández-Jiménez, A. and A. Palomo, Alkaline Activation of Fly Ashes. Manufacture of Concrete Not Containing Portland Cement, in International RILEM Conference on the Use of Recycled Materials in Buildings and Structures. p. 8.(2004)

5. Diaz-Loya, E.I., E. Allouche, and S. Vaidya, Mechanical Properties of Fly-Ash-Based Geopolymer Concrete. ACI Materials Journal. 108(3): p. 300-306.(2011)

6. Gourley, T.J. and G.B. Johnson. Development in Geopolymer Precast Concrete. in International Workshop on Geopolymers and Geoplymer Concrete. Perth, Australia.(2005)

7. Rickard, W., et al., Assessing the suitability of three Australian fly ashes as an aluminosilicate source for geopolymers in high temperature applications. Materials Science and Engineering: A. 528: p. 3390-3397.(2011)

8. Diaz-Loya, E.I., E. Allouche, and S. Eklund, Factors Affecting the Suitability of Fly Ash as Source Material for Geopolymers. Fuel. 89: p. 992-996.(2010)

9. Neville, A., Properties of Concrete. 4th ed: Longman Group Limited.(1995)

10. A. Ferna'ndez-Jime'nez, et al., New Cementitious Materials Based on Alkali-Activated Fly Ash: Performance at High Temperatures. Journal of American Ceramic Society. 91(10): p. 3308-3314.(2008)

11. Bakharev, T., Thermal behaviour of geopolymers prepared using class $F$ fly ash and elevated temperature curing. Cement \& Concrete Research. 36: p. 1134-1147.(2006)

12. Rickard, W., J. Temuujin, and A. van Riessen, Thermal analysis of geopolymer pastes synthesised from five fly ashes of variable composition. Journal of Non-Crystalline Solids. 358: p. 1830-1839.(2012)

13. Rickard, W., L. Vickers, and A. van Riessen, Performance of fibre reinforced, low density metakaolin geopolymers under simulated fire conditions. Applied Clay Science. 73: p. 71-77.(2013)

14. Guerrieri, M., J. Sanjayan, and F. Collins, Residual strength properties of sodium silicate alkali activated slag paste exposed to elevated temperatures. Journal of Materials and Structures. 43(6): p. 765-773.(2007)

15. Guerrieri, M., J. Sanjayan, and F. Collins, Residual compressive behavior of alkaliactivated concrete. Journal of Fire and Materials. 33(1): p. 51-62.(2007)

16. Guerrieri, M. and J. Sanjayan, Behavior of combined fly ash/slag based geopolymers when exposed to high temperatures. Journal of Fire and Materials. 34(4): p. 163175.(2009)

17. Provis, J., Fire resistance of geopolymer concretes, University of Melbourne: Melbourne.(2010)

18. Provis, J., et al., Correlating Mechanical and Thermal Properties of Sodium SilicateFly Ash Geopolymers. Colloids and Surfaces A: Physicochemical and Engineering Aspects. 336(1-3): p. 57-63.(2009) 
19. Junaid, M.T., et al., Aspects of the deformational behaviour of alkali activated fly ash concrete at elevated temperatures. Cement \& Concrete Research. 60: p. 24-29.(2014)

20. Junaid, M.T., O. Kayali, and A. Khennane, Response of alkali activated low calcium fly-ash based geopolymer concrete under compressive load at elevated temperatures. Materials and Structures. 50(1): p. 50.(2017)

21. Junaid, M.T., A. Khennane, and O. Kayali, Investigation into the Effect of the Duration of Exposure on the Behavior of Geopolymer Concrete at Elevated Temperatures. MATEC Web of Conferences. 11.(2014)

22. Junaid, M.T., A. Khennane, and O. Kayali, Performance of fly ash based geopolymer concrete made using non-pelletized fly ash aggregates after exposure to high temperatures. Materials and Structures.(2014)

23. Pan, Z., J. Sanjayan, and F. Collins, Effect of transient creep on compressive strength of geopolymer concrete for elevated temperature exposure. Cement and Concrete Research. 56: p. 182-189.(2014)

24. Davidovits, J., Geopolymers and geopolymeric materials. Journal of Thermal Analysis and Calorimetry. 35(2): p. 429-441.(2005)

25. Rangan, B., Design and Manufacture of fly-ash based geopolymer concrete. Concrete in Australia. 34(2): p. 37-43.(2010)

26. Junaid, M.T., et al., A mix design procedure for low calcium alkali activated fly ashbased concretes. Construction and Building Materials. 79: p. 301-310.(2015) 